\title{
Optimization of pulping method for extraction of pulp from ripe persimmon (Diospyros kaki L.) and its stability during storage
}

\author{
Anjali Gautam \\ Department of Food Science and Technology, Dr YS Parmar University of Horticulture and \\ Forestry, Nauni, Solan-173230 (HP), India \\ Anju K Dhiman \\ Department of Food Science and Technology, Dr YS Parmar University of Horticulture and \\ Forestry, Nauni, Solan-173230 (HP), India \\ Surekha Attri \\ Department of Food Science and Technology, Dr YS Parmar University of Horticulture and \\ Forestry, Nauni, Solan-173230 (HP), India \\ Deepika Kathuria* \\ Department of Food Science and Technology, Dr YS Parmar University of Horticulture and \\ Forestry, Nauni, Solan-173230 (HP), India \\ *Corresponding author. Email: deepukathuria@gmail.com
}

\section{Article Info}

https://doi.org/10.31018/

jans.v12i4.2430

Received: October 28, 2020

Revised: December 3, 2020

Accepted: December 6, 2020

\section{How to Cite}

Gautam A. et al. (2020). Optimization of pulping method for extraction of pulp from ripe persimmon (Diospyros kaki L.) and its stability during storage. Journal of Applied and Natural Science, 12(4): 618 - 627. https://doi.org/10.31018/jans.v12i4.2430

\begin{abstract}
Persimmon fruit (Diospyros kaki L.) is a highly nutritious fruit with bestowed antioxidant properties. But due to its perishable nature, it is produced for a very shorter period of time. Preservation of fruit in the form of pulp acts as a suitable method to provide availability of the fruit throughout the year. The main objective of this investigation was to develop persimmon pulp from the cold and hot pulping method and to assess the best preservation method for storage. Among six different treatments in cold pulping method ( $T_{1}$ to $\left.T_{3} \times 2\right)$, treatment $T_{2}\left(10 \%\right.$ water) and among 18 different treatment in hot pulping method $\left(T_{1}\right.$ to $\left.T_{9} \times 2\right)$, treatment $\mathrm{T}_{5}(10 \%$ water +10 minutes cooking time) using fruit with peel was selected on the basis of nutritional and sensory attributes. Further, the pulp was preserved via heat and chemical methods. Among six different treatments, $T_{5}$ (Pulp + pasteurization $+1000 \mathrm{ppm}$ potassium metabisulphite (KMS) in glass bottles) was found to be best in the type of pulp. This treatment was able to retain the maximum amount of ascorbic acid $(13.733$ and $8.043 \mathrm{mg} / 100 \mathrm{~g}), \beta$-carotene $(173 \mathrm{and} 86 \mu \mathrm{g} / 100 \mathrm{~g})$ and total phenols $(3.093$ and $2.873 \mathrm{mg} / 100 \mathrm{~g})$, respectively during storage of 6 months. Hence, it can be suggested from the study that nutritionally rich persimmon pulp can be prepared with better storage stability which can be used by both small and large scale industries at a lower cost of production.
\end{abstract}

Keywords: Ripe persimmon, Pulp, Pulping method, Pulp preservation, KMS

\section{INTRODUCTION}

Fruits and vegetables are the most perishable food products that get spoiled as early as possible, so they need to be converted into edible products. The most important way to utilize fruits and vegetables is to produce semi-finished products such as pulps, purees, juices, etc. The pulp can be extracted by employing various methods such as hot and cold pulping, enzymatic treatment, microwave extraction, high-pressure treatment, ultrasonic extraction, etc. The quality of fruit pulps must be maintained using various quality control methods, in order to offer a high nutritional, microbiological and sensory quality product to the consumers. Different preservation methods can be used to pre- serve the nutrition, color and taste of the fruit pulp. To check efficacy and effects on microbial culture growth use of chemical preservatives is of prime importance (Khattak et al., 2014).

Persimmon (Diospyros kakai L.) is a Japanese fruit commonly known as Japani phal. The word persimmon is derived from Algonquian called as "dry fruit". Ancient refers persimmon fruit as "Food for the Gods" where Dios means God and pyros means food or grain. The fruit is native to China, Korea and Japan, but is widely cultivated in warm regions of Brazil, Italy and the Mediterranean region as well (Bubba et al., 2009). As per FAO report, the total annual production of persimmon is more than 7.9 million tonnes in the world of which 85 per cent of total production is from 
China, Japan and Korea in the year 2018 (FAO, 2018). The fruit is cherished for its unique flavour and high nutrient content. It contains $82.03 \%$ water, $0.61 \%$ protein, $19.6 \%$ carbohydrate and $0.40 \%$ fat (Zhou et al., 2011). The Fuyu variety has higher levels of sugars. Fructose and glucose are main sugars present in fruit comprising of more than 90 per cent of total sugar while sucrose is present in minimum level (Itoo, 1980). Other than nutrients persimmon is potentially a rich source functional components such as Vitamin A, D, E, B6 and B12, carotenoids, polyphenolic compounds, flavonoids and flavonols. These bioactive components acquire potential role against oxidation of LDL cholesterol and arterial stiffness that results in atherosclerotic plague formation. Further, they possess antioxidant and antimutagenic effect that activate the immune response, resulting in the normal functioning of metabolic activities (Butt et al., 2015).

Fuyu persimmons are highly versatile as they can be eaten fresh out of hand. The fruits are sweet; their texture varies from crisp and succulent when young, to a tender and gelatinous as they mature. The fresh Fuyu fruits can be stored for a period of 20-30 days while its shelf life can be increased up to 2 months when stored at $0^{\circ} \mathrm{C}$ (Jung et al., 2005). Being nutrients enrich fruit, ripe persimmon has major post-harvest problems related to handling, packaging, storage, transportation and marketing (Unal et al., 2018). Thus proper processing steps have to follow to save the crop from wastage and conserve its nutrients. Therefore, an important way to avoid post-harvest losses is to process the fruit in the form of pulp. Although different preparation and preservation methods have been examined, there are few studies concerning persimmon pulp and its addition in food and food products.

Keeping in view the above facts, the efforts have been made in the present study in order to prepare and improve the shelf life of ripe persimmon pulp by using the various safe preservation methods under their acceptable limits.

\section{MATERIALS AND METHODS}

Preparation of persimmon pulp: The fully ripened persimmon fruits of Fuyu variety were procured from the Regional Horticulture Research and Training Station Seobahg, Kullu, Himachal Pradesh and used for the preparation and preservation of pulp. The pulp from ripe persimmon fruit was extracted by employing cold and hot pulping methods (Dhiman et al., 2018). The persimmon fruits were divided into two lots comprising of fruits with peel and the fruits without the peel. The ripe persimmons were thoroughly washed. The calyx was removed manually with the help of stainless steel knife and cut into halves. The seeds and the peel (only in case of pulp without peel) were also removed manually. The fruits were cut into small pieces and converted into pulp by grinding in a mixer cum grinder (Model MX-1155). The amount of water (5, 10 and 15
$\%$ ) to be added for the preparation of ripe persimmon pulp was standardization of cold pulping method. Therefore, six $\left(T_{1}\right.$ to $\left.T_{3} \times 2\right)$ treatments were involved for the development of pulp using fruit with peel $(5,10$ and $15 \%$ of water) and fruit without peel $(5,10$ and 15 $\%$ of water). A similar process was followed in case of the hot pulping method as well, the fruits pieces were heated in a pressure cooker ( $5 \mathrm{~kg}$ capacity) on a domestic gas stove. The different treatment combinations having varied quantity of water $(5,10$ and $15 \%)$ and cooking time $(5,10,15 \mathrm{~min})$ were used for standardization of hot pulping method for preparation of ripe persimmon pulp. Hence, eighteen ( $T_{1}$ to $\left.T_{9} \times 2\right)$ total treatments were used, comprising of nine treatments using fruit with peel and nine treatments using fruit without the peel. The pulp thus obtained was analyzed for different chemical parameters and the best combination on the basis of higher retention of nutrients as well as sensory scores was selected for further studies.

Preservation of persimmon pulp: The pulp of best treatment obtained from cold and hot pulping method was preserved by different treatments viz. $\mathrm{T}_{1}(2000$ ppm KMS), $T_{2}$ (2000 ppm sodium benzoate), $T_{3}$ (1000 ppm KMS + 1000 ppm sodium benzoate), $\mathrm{T}_{4}$ (Pasteurization), $\mathrm{T}_{5}$ (Pasteurization + 1000 ppm KMS) and $\mathrm{T}_{6}$ (Pasteurization $+1000 \mathrm{ppm}$ sodium benzoate). As per preservation method, the pulp was packed in glass jars and glass bottle and was labelled properly. Further, the product was kept at ambient temperature and quality was evaluated at 0,3 and 6 months of storage interval.

Chemical and microbial examination: The ripe persimmon pulp was analyzed for different parameters. Total Soluble solids (TSS) were measured by hand refractometer of $0-32{ }^{\circ}$ Brix (Ranganna, 2009). Standard $0.1 \mathrm{~N} \mathrm{NaOH}$ solutions was used for determination of titrable acidity for titrating known volume of sample in the presence of phenolphthalein as an indicator (Ranganna, 2009). A digital pH meter (CRISON Instrument, Ltd Spain) was used to analyze pH of the sample. The method as suggested by Ranganna (2009) was followed for the evaluation of sugars, ascorbic acid and $\beta$-carotene. Total phenols were analyzed per the method suggested by Singleton and Rossi (1965) using gallic acid as standard. Total plate count was done under aseptic conditions, in which $0.1 \mathrm{~g}$ of serially diluted samples was inoculated on standard plate count agar medium (Ranganna, 2009). Then the plates were incubated at $37^{\circ} \mathrm{C}$ for 72 hours prior to the counting of microbes. The results of total plate count (TPC) were expressed as CFU/mL of sample.

Sensory evaluation: The persimmon pulp was subjected to sensory evaluation and ranking was done based on nine-point hedonic rating method (Amerine et al., 1965) was followed for conducting the study. Ten semi-trained panellists, including faculty members and postgraduate students of the Department of Food Science and Technology, were selected for product 
evaluation. Each product was judged for various sensory parameters such as colour, consistency, taste, aroma and overall acceptability on the basis of nine points hedonic scale.

Statistical analysis: The data collected on chemical characteristics of persimmon pulp as per the experiment were analyzed by using Completely Randomized Design (CRD) and data pertaining to sensory evaluation were analyzed by Randomized Block Design (RBD). Further, to compare the quality of persimmon pulp extracted using the different pulping method, the mean value of each parameter was analyzed using paired t-test.

\section{RESULTS AND DISCUSSION}

Standardization of cold pulping method for preparation of ripe persimmon pulp: The data pertaining to chemical characteristics of ripe persimmon pulp extracted by cold pulping method is presented in Table 1. After going through the data it was revealed that, there were significant differences with respect to pulp recovery, $\mathrm{pH}$, reducing sugars, ascorbic acid and $\beta$ carotene of persimmon pulp extracted by three different combinations of water using fruit with and without the peel. The recovery of pulp was higher where fruit along with peel was used for the preparation of pulp. It was found that the presence of peel in pulp had significant $(p<0.05)$ difference in the recovery of persimmon pulp. The pulp recovery ranged from 77.32 to 79.95 and 72.55 to 75.82 per cent $(\mathrm{w} / \mathrm{w})$ in persimmon pulp prepared using fruit with and without the peel. Further, fruit to water ratio brought a significant $(p<0.05)$ effect on the yield of pulp, i.e. with an increase in water content the yield of pulp also increased. Similarly, the yield was increased with the addition of water as reported by Sharma et al. (2019) on extracting pulp using Hachiya variety of persimmon by the cold pulping method. The total soluble solids (TSS) of extracted pulp obtained from fruit with and without peel decreased from 15.64 to 15.56 and 15.60 to $15.37^{\circ} \mathrm{Brix}$. The treatment $T_{1}$ in both the case exhibited the highest TSS, which was statistically at par with $T_{2}$ while $T_{3}$ showed the lowest level. With the increase in the proportion of water in the fruit, the TSS of pulp exhibited non-significant decrease. The titratable acidity was highest $(0.125 \%)$ in $T_{1}$ and was statistically at par $(p<0.05)$ with treatment $T_{2}$ and $T_{3}$ in pulp extracted using fruit with and without the peel. The $\mathrm{pH}$ value was maximum in treatment $T_{3}(5.81$ and 5.68) and minimum in $T_{1}$ (5.78 and 5.57) thereby indicating an inverse relation with titratable acidity for the respective pulp. Siloni (2013) reported that dilution of fruit slices in water in different proportions brought about a significant $(p<0.05)$ difference in titratable acidity and $\mathrm{pH}$ of extracted guava pulp. Similar to TSS, total sugars and reducing sugars in all treatments ranged from 13.91 to 13.97 and 11.83 to 11.92 per cent, respectively in pulp extracted by fruit with peel while ranged from 13.61 to
13.70 and 11.65 to 11.74 per cent, respectively in pulp extracted by fruit without the peel. It means that dilution decreased the amount of sugars. If we talk about functional components, addition water had significant $(p<0.05)$ effect on the concentration of ascorbic acid, $\beta$-carotene and total phenols. The ascorbic acid was observed to be higher in $T_{1}$ with a value of 15.32 and 14.76 and lower in $T_{3}$ with a value of 14.86 and 14.63 $\mathrm{mg} / 100 \mathrm{~g}$, respectively in pulp containing fruit peel and without the peel. In the case of $\beta$-carotene, presence of peel had a greater impact on it which means that fruit peel does possess a higher amount of $\beta$ carotene. The value for $\beta$-carotene ranged from 180 to 240 and 140 to $180 \mu \mathrm{g} / 100 \mathrm{~g}$ in the respective pulp. While total phenols were highest $(3.80$ and 3.70 $\mathrm{mg} / 100 \mathrm{~g})$ in $T_{1}$ which was statistically at par $(p<0.05)$ with treatment $T_{2}$ having a value of 3.77 and 3.67 $\mathrm{mg} / 100 \mathrm{~g}$ and $T_{3}$ with a value of 3.74 and 3.62 $\mathrm{mg} / 100 \mathrm{~g}$, respectively in pulp extracted using fruit with and without the peel. An appraisal of data (Table 1) revealed the maximum colour score (8.48) in $T_{2}$ as compared to $T_{1}$ and $T_{3}$. Maximum mean scores for consistency (8.01), taste (8.35), aroma (7.49) and overall acceptability (8.48) were also awarded to $T_{2}$ in pulp extracted using fruit with the peel. Similarly, in the case of pulp obtained from the fruit without peel, the assessment of data reported maximum colour score (7.45) in $T_{2}$, which was statistically at par with $\mathrm{T}_{3}$. Maximum mean scores for consistency taste and overall acceptability was $7.97,7.90$ and 7.45 , respectively in $\mathrm{T}_{2}$. Therefore, on the basis of nutritional and sensory characteristics, it is concluded that the pulp extracted using fruits with peel by adding 10 per cent of water was observed to be the best and selected for storage studies.

Standardization of hot pulping method for preparation of ripe persimmon pulp: The chemical analyze of ripe persimmon pulp extracted by the hot pulping method is given in Table 2. The data revealed significant differences $(p<0.05)$ among chemical parameters of ripe persimmon pulp extracted by different combinations of water while ascorbic acid and total phenols possess non-significant effect $(p<0.05)$ on the increase in cooking time in fruit with and without the peel. In this method, TSS, total sugar and reducing sugars was decreased with increase in the water while increase with the increase in cooking time, on the other hand, $\mathrm{pH}$ increase while titratable acidity, functional components decreases with increase in water and cooking time. The recovery of pulp was higher when fruit along with peel was used in comparison to flesh alone. It was observed from the data that the pulp recovery was maximum (89.88 and $80.32 \%)$ in $\mathrm{T}_{7}$ and minimum ( 80.15 and $76.71 \%$ ) in $\mathrm{T}_{3}$. The data showed that the addition of water exerted a significant increase while cooking time possesses significant $(p<0.05)$ decrease in the yield of persimmon pulp. A higher yield of guava pulp and pumpkin pulp 
Table 1. Physico-chemical characteristics and sensory score of cold extracted persimmon pulp from fruit with and without the peel.

\begin{tabular}{|c|c|c|c|c|c|c|c|c|}
\hline \multirow{2}{*}{ Parameter } & \multicolumn{4}{|c|}{ Persimmon pulp with peel } & \multicolumn{4}{|c|}{ Persimmon pulp without peel } \\
\hline & $\mathrm{T}_{1}$ & $\mathbf{T}_{2}$ & $\mathrm{~T}_{3}$ & $\mathrm{CD}_{0.05}$ & $\mathrm{~T}_{1}$ & $\mathrm{~T}_{2}$ & $\mathrm{~T}_{3}$ & $C D_{0.05}$ \\
\hline Pulp recovery $(\%)$ & 77.32 & 77.8 & 79.95 & 0.05 & 72.55 & 72.85 & 75.82 & 0.06 \\
\hline TSS $\left({ }^{\circ} \mathrm{B}\right)$ & 15.64 & 15.58 & 15.56 & 0.06 & 15.60 & 15.57 & 15.37 & 0.04 \\
\hline Titratable acidity (\%) & 0.125 & 0.121 & 0.118 & 0.045 & 0.125 & 0.123 & 0.121 & 0.045 \\
\hline $\mathrm{pH}$ & 5.78 & 5.87 & 5.81 & 0.04 & 5.57 & 5.61 & 5.68 & .04 \\
\hline Total sugars (\%) & 13.97 & 13.93 & 13.91 & 0.04 & 13.70 & 13.65 & 13.61 & 0.04 \\
\hline Reducing sugars (\%) & 11.92 & 11.88 & 11.83 & 0.04 & 11.74 & 11.68 & 11.65 & 0.07 \\
\hline Ascorbic acid $(\mathrm{mg} / 100 \mathrm{~g})$ & 15.32 & 15.12 & 14.86 & 0.07 & 14.76 & 14.70 & 14.63 & 0.04 \\
\hline$\beta$-carotene $(\mu \mathrm{g} / 100 \mathrm{~g})$ & 240 & 220 & 180 & 0.04 & 180 & 155 & 140 & 0.04 \\
\hline Total phenols (mg/100g) & 3.80 & 3.77 & 3.74 & 0.04 & 3.70 & 3.67 & 3.62 & 0.04 \\
\hline Color & 8.16 & 8.48 & 8.34 & 0.02 & 7.28 & 7.45 & 7.40 & 0.02 \\
\hline Consistency & 7.05 & 8.01 & 7.55 & 0.13 & 7.01 & 7.97 & 7.50 & 0.02 \\
\hline Taste & 8.02 & 8.35 & 8.27 & 0.01 & 7.27 & 7.90 & 7.25 & 0.02 \\
\hline Aroma & 7.18 & 7.49 & 7.32 & 0.03 & 6.80 & 6.89 & 6.83 & 0.02 \\
\hline Overall acceptability & 8.29 & 8.48 & 8.37 & 0.01 & 7.28 & 7.45 & 7.40 & 0.02 \\
\hline
\end{tabular}

where, $\mathrm{T}_{1}=5 \%$ water, $\mathrm{T}_{2}=10 \%$ water, $\mathrm{T}_{3}=15 \%$ water, $\mathrm{CD}_{0.05}$ is $5 \%$ level of significance

was recorded on increasing the proportion of water during extraction by the hot pulping method by Sandhu et al. (2001) and Dhiman et al. (2018), respectively. The TSS was ranged from 15.12 to $15.95^{\circ} \mathrm{Brix}$ and from 14.21 to $15.28{ }^{\circ} \mathrm{Brix}$ in the pulp obtains from fruit with and without peel, respectively. Heating during pulp extraction helps in increasing the total soluble solids of the pulp due to loss of moisture and better extraction of soluble components. Similar results were reflected by Siloni (2013) for guava pulp when cooked for $15 \mathrm{~min}$ and Dhiman et al. (2018) for pumpkin pulp when cooked for $10 \mathrm{~min}$. The titratable acidity was observed to have maximum value in $\mathrm{T}_{1}(0.121$ and $0.112 \%)$ and least in $T_{9}(0.103$ and $0.095 \%)$, in the respective pulp. While the inverse relation was observed in case of $\mathrm{pH}$, as higher the acidity lower is the $\mathrm{pH}$ value. Among two different types of pulp, pulp consisting of fruit peel possessed greater acidity and might have good stability. The total sugars and reducing sugars were between 14.10 to 14.36 and 12.11 to 12.67 per cent, respectively in persimmon pulp consisting of fruit peel and 14.03 to 14.24 per cent and 12.09 to 12.52 per cent, respectively in persimmon pulp with no fruit peel. The functional components like ascorbic acid, $\beta$-carotene and total phenols were observed to be highest in $T_{1}$ and lowest in $T_{9}$ which means that both dilution and cooking time had decreased the amount of these functional components. The ascorbic acid content ranged from 8.75 to 11.13 and 8.32 to $10.51 \mathrm{mg} / 100 \mathrm{~g}$ in the respective pulp. The maximum value of $\beta$-carotene and total phenols was observed to be 200 and $3.75 \mathrm{mg} / 100 \mathrm{~g}$ in persimmon pulp extracted using fruit with peel and a value of 160 and $3.71 \mathrm{mg} / 100 \mathrm{~g}$ in persimmon pulp extracted using fruit without peel, respectively. It means that fruit peel does possess functional properties also. The loss in ascorbic acid content in hot pulping may due to the reason that the vitamin is heat-labile. The results are in conformation with the findings of Bembem and Sadana (2013) who revealed a significant $(p<0.05)$ decrease in ascorbic acid of potato when cooked in boiling water followed by pressure cooking, steaming, microwave cooking and sauteing. The report of Pott et al. (2003) reflects $7.7 \%$ to $15.4 \%$ decrease in $\beta$-carotene after pasteurization of mango puree for $15 \mathrm{~min}$. Also, the decreased in $\beta$-carotene from 6.22 to $5.31 \mathrm{mg} / 100 \mathrm{~g}$ when cooked for 3 to 10 min was observed by Dhiman et al. (2018) in ripe pumpkin pulp.

Further, data indicated in Table 2 reported that treatment $T_{5}$ got the maximum score for colour (8.46), consistency (7.75), taste (8.26), aroma (7.91), and overall acceptability (8.39) reflecting the product was liked very much by the panellist for the pulp prepared using fruit with peel. While in case of persimmon pulp prepared using fruit without peel had maximum overall acceptability $(7.38)$ in $T_{5}$ (10\% water and 10 min cooking time) and minimum (7.21) was found in $\mathrm{T}_{9}(15 \%$ water and 15 min cooking time). The maximum mean scores for color (7.41), consistency (7.72), taste (7.24) and aroma (6.90) was awarded to $T_{5}(10 \%$ water and 10 min cooking time). It was observed that the increase in cooking time to $15 \mathrm{~min}$ at reduced water level caused burnt flavor in pulp. Therefore, based on both nutritional quality and sensory attributes, the hot pulping of persimmon fruits with peel after addition of 10 per cent water was followed by cooking for $10 \mathrm{~min}$ 
Gautam A. et al. / J. Appl. \& Nat. Sci. 12(4): 618 - 627 (2020)

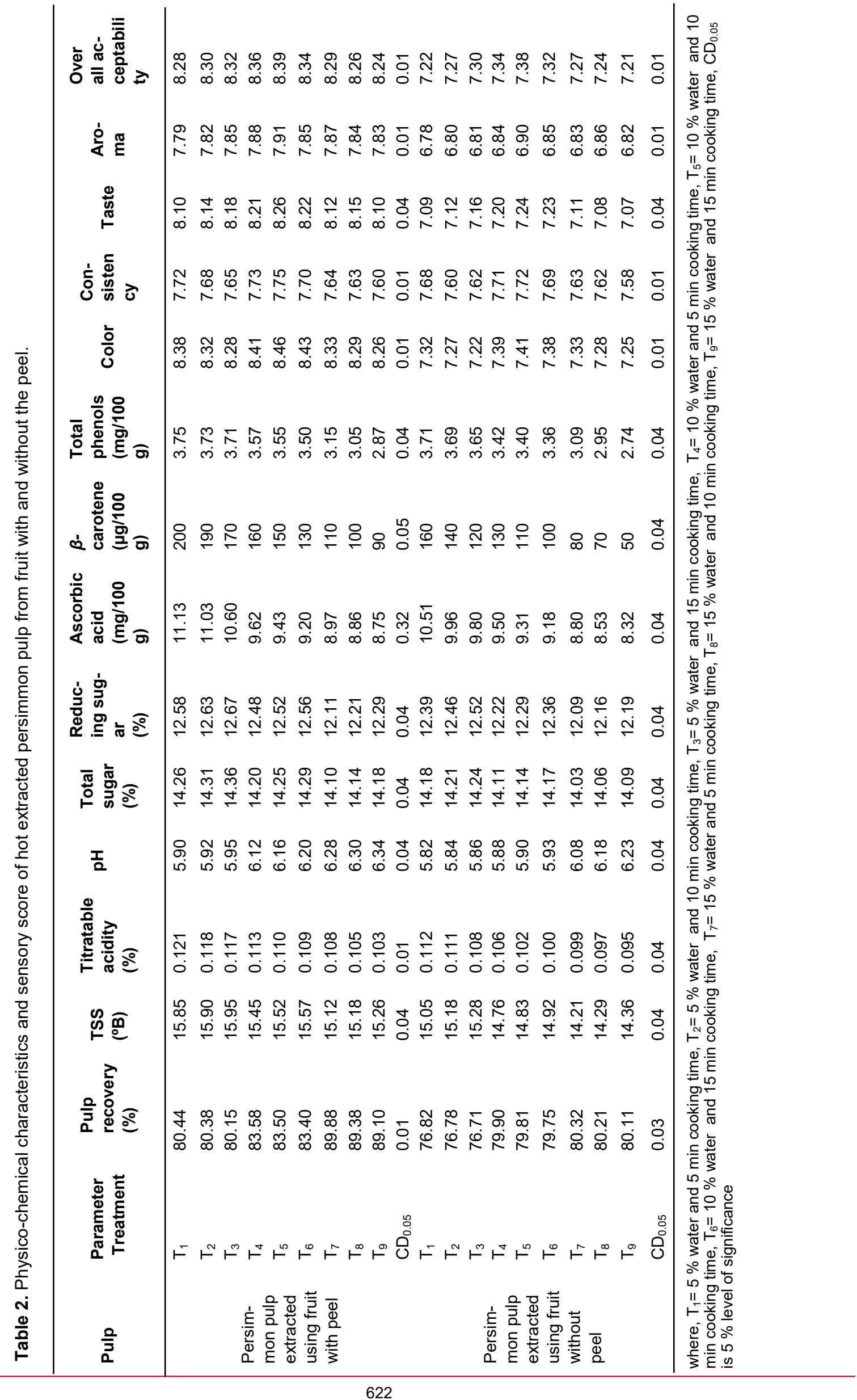


Table 3. Storage study of persimmon pulp extracted by the cold pulping method.

\begin{tabular}{|c|c|c|c|c|c|c|c|c|c|}
\hline \multirow{2}{*}{ Parameters } & \multirow{2}{*}{$\begin{array}{l}\text { Storage } \\
\text { interval }\end{array}$} & \multicolumn{6}{|c|}{ Treatments } & \multirow{2}{*}{ Mean } & \multirow{2}{*}{$C D_{0.05}$} \\
\hline & & $\mathrm{T}_{1}$ & $\mathrm{~T}_{2}$ & $\mathbf{T}_{3}$ & $T_{4}$ & $\mathrm{~T}_{5}$ & $\mathbf{T}_{6}$ & & \\
\hline \multirow{4}{*}{ TSS ( ${ }^{\circ}$ Brix) } & 0 & 15.56 & 15.56 & 15.56 & 15.88 & 15.88 & 15.88 & 15.723 & \multirow{4}{*}{$\begin{array}{l}T=0.014 \\
S=0.02 \\
S \times T=0.034\end{array}$} \\
\hline & 3 & 15.59 & 15.76 & 15.86 & 16.01 & 15.92 & 15.98 & 15.856 & \\
\hline & 6 & 16.05 & 16.11 & 16.21 & 16.50 & 16.34 & 16.38 & 16.267 & \\
\hline & Mean & 15.73 & 15.81 & 15.88 & 16.13 & 16.05 & 16.08 & & \\
\hline \multirow{4}{*}{$\begin{array}{l}\text { Titrable acidity } \\
(\%)\end{array}$} & 0 & 0.12 & 0.12 & 0.12 & 0.09 & 0.09 & 0.09 & 0.10 & \multirow{4}{*}{$\begin{array}{l}T=0.001 \\
S=0.002 \\
S \times T=0.003\end{array}$} \\
\hline & 3 & 0.13 & 0.15 & 0.15 & 0.10 & 0.09 & 0.10 & 0.12 & \\
\hline & 6 & 0.15 & 0.18 & 0.19 & 0.11 & 0.10 & 0.12 & 0.14 & \\
\hline & Mean & 0.13 & 0.15 & 0.15 & 0.10 & 0.09 & 0.10 & & \\
\hline \multirow{4}{*}{$\mathrm{pH}$} & 0 & 5.81 & 5.81 & 5.81 & 5.78 & 5.78 & 5.78 & 5.80 & \multirow{4}{*}{$\begin{array}{l}T=0.014 \\
S=0.02 \\
S \times T=N S\end{array}$} \\
\hline & 3 & 5.79 & 5.77 & 5.75 & 5.76 & 5.74 & 5.72 & 5.76 & \\
\hline & 6 & 5.70 & 5.67 & 5.64 & 5.67 & 5.64 & 5.61 & 5.65 & \\
\hline & Mean & 5.77 & 5.75 & 5.73 & 5.74 & 5.72 & 5.70 & & \\
\hline \multirow{4}{*}{$\begin{array}{l}\text { Total sugars } \\
(\%)\end{array}$} & 0 & 13.62 & 13.62 & 13.62 & 13.96 & 13.96 & 13.96 & 13.79 & \multirow{4}{*}{$\begin{array}{l}T=0.014 \\
S=0.02 \\
S \times T=0.035\end{array}$} \\
\hline & 3 & 13.65 & 13.78 & 13.89 & 14.07 & 13.99 & 14.04 & 13.91 & \\
\hline & 6 & 14.07 & 14.11 & 14.20 & 14.52 & 14.36 & 14.42 & 14.28 & \\
\hline & Mean & 13.78 & 13.84 & 13.91 & 14.18 & 14.11 & 14.14 & & \\
\hline \multirow{4}{*}{$\begin{array}{l}\text { Reducing } \\
\text { sugars (\%) }\end{array}$} & 0 & 11.71 & 11.71 & 11.71 & 11.75 & 11.75 & 11.75 & 11.73 & \multirow{4}{*}{$\begin{array}{l}T=0.014 \\
S=0.02 \\
S \times T=0.035\end{array}$} \\
\hline & 3 & 11.73 & 11.87 & 11.98 & 12.06 & 11.78 & 11.83 & 11.87 & \\
\hline & 6 & 12.15 & 12.20 & 12.30 & 12.38 & 12.16 & 12.21 & 12.23 & \\
\hline & Mean & 6.86 & 6.93 & 12.00 & 12.06 & 11.90 & 11.93 & & \\
\hline \multirow{4}{*}{$\begin{array}{l}\text { Ascorbic } \\
\text { acid (mg/100g) }\end{array}$} & 0 & 15.12 & 15.12 & 15.12 & 14.86 & 14.86 & 14.86 & 14.99 & \multirow{4}{*}{$\begin{array}{l}T=0.014 \\
S=0.02 \\
S \times T=0.034\end{array}$} \\
\hline & 3 & 14.00 & 13.49 & 13.82 & 13.62 & 13.73 & 13.81 & 13.74 & \\
\hline & 6 & 12.89 & 11.86 & 12.53 & 12.39 & 12.60 & 12.77 & 12.51 & \\
\hline & Mean & 14.02 & 13.49 & 13.83 & 13.63 & 13.73 & 13.82 & & \\
\hline \multirow{4}{*}{$\begin{array}{l}\beta \text {-carotene } \\
(\mathrm{mg} / 100 \mathrm{~g})\end{array}$} & 0 & 223 & 223 & 223 & 193 & 193 & 193 & 213 & \multirow{4}{*}{$\begin{array}{l}T=0.010 \\
S=0.02 \\
S \times T=0.033\end{array}$} \\
\hline & 3 & 203 & 193 & 183 & 173 & 173 & 163 & 183 & \\
\hline & 6 & 183 & 163 & 143 & 163 & 153 & 133 & 153 & \\
\hline & Mean & 203 & 193 & 183 & 183 & 173 & 163 & & \\
\hline \multirow{4}{*}{$\begin{array}{l}\text { Total phenols } \\
(\mathrm{mg} / 100 \mathrm{~g})\end{array}$} & 0 & 3.77 & 3.77 & 3.77 & 3.45 & 3.45 & 3.45 & 3.61 & \multirow{4}{*}{$\begin{array}{l}T=0.010 \\
S=0.02 \\
S \times T=0.034\end{array}$} \\
\hline & 3 & 3.13 & 3.27 & 3.30 & 3.10 & 3.09 & 3.09 & 3.19 & \\
\hline & 6 & 2.85 & 2.78 & 2.81 & 2.76 & 2.73 & 2.74 & 2.78 & \\
\hline & Mean & 3.13 & 3.27 & 3.29 & 3.11 & 3.09 & 3.10 & & \\
\hline
\end{tabular}

where, $T=$ treatment, $S=$ storage, $C D_{0.05}$ is $5 \%$ level of significance

was selected for storage studies.

Comparison of persimmon pulp extracted using different pulping method: To determine the hypothesis about the mean difference of various physicochemical characteristics, paired t-test was used to analyze the effect of pulp extraction method that cause significant changes in all the parameters including pulp recovery, TSS, titratable acidity, $\mathrm{pH}$, total sugars, reducing sugars, ascorbic acid, $\beta$-carotene and total phenols. Therefore, it reflected that cooking of pulp lead to higher pulp recovery along with better consistency due to tissue breakdown and inactivation of pectinase. Further heating caused the breakdown of polysaccharides into simple sugars. Although the color of pulp obtained by hot pulping had good characteristic, heating lead to loss of heat-sensitive components such as ascorbic acid, $\beta$-carotene and total phenols.

Change in chemical and microbial parameters of persimmon pulp preserved by different methods during storage: The data presented in Table 3 and 4 revealed a gradual increase in the TSS, titratable acidity, total sugars and reducing sugars while decreasing trend was observed in $\mathrm{pH}$ when pulp was stored for 6 months applied with different methods of preservation. 
Gautam A. et al. / J. Appl. \& Nat. Sci. 12(4): 618 - 627 (2020)

Table 4. Storage study of persimmon pulp extracted by hot pulping method.

\begin{tabular}{|c|c|c|c|c|c|c|c|c|c|}
\hline \multirow{2}{*}{ Parameters } & \multirow{2}{*}{$\begin{array}{l}\text { Storage } \\
\text { interval }\end{array}$} & \multicolumn{6}{|c|}{ Treatments } & \multirow{2}{*}{ Mean } & \multirow{2}{*}{$C D_{0.05}$} \\
\hline & & $T_{1}$ & $\mathrm{~T}_{2}$ & $T_{3}$ & $\mathrm{~T}_{4}$ & $\mathrm{~T}_{5}$ & $T_{6}$ & & \\
\hline \multirow{4}{*}{ TSS ( ${ }^{\circ}$ Brix) } & 0 & 15.62 & 15.62 & 15.62 & 15.94 & 15.94 & 15.94 & 15.78 & \multirow{4}{*}{$\begin{array}{l}T=0.188 \\
S=0.267 \\
S \times T=N S\end{array}$} \\
\hline & 3 & 15.66 & 15.82 & 15.92 & 16.07 & 16.01 & 16.04 & 15.92 & \\
\hline & 6 & 16.12 & 16.19 & 16.27 & 16.25 & 16.13 & 16.44 & 16.28 & \\
\hline & Mean & 15.80 & 15.87 & 15.94 & 16.08 & 16.02 & 16.14 & & \\
\hline \multirow{4}{*}{$\begin{array}{l}\text { Titrable acidity } \\
(\%)\end{array}$} & 0 & 0.108 & 0.108 & 0.108 & 0.078 & 0.078 & 0.078 & 0.09 & \multirow{4}{*}{$\begin{array}{l}T=0.001 \\
S=0.002 \\
S \times T=0.003\end{array}$} \\
\hline & 3 & 0.123 & 0.138 & 0.143 & 0.08 & 0.08 & 0.093 & 0.11 & \\
\hline & 6 & 0.138 & 0.168 & 0.178 & 0.09 & 0.088 & 0.108 & 0.13 & \\
\hline & Mean & 0.123 & 0.138 & 0.143 & 0.083 & 0.09 & 0.093 & & \\
\hline \multirow{4}{*}{$\mathrm{pH}$} & 0 & 6.16 & 6.16 & 6.16 & 6.11 & 6.11 & 6.11 & 6.14 & \multirow{4}{*}{$\begin{array}{l}T=0.014 \\
S=0.02 \\
S \times T=N S\end{array}$} \\
\hline & 3 & 6.14 & 6.12 & 6.10 & 6.09 & 6.07 & 6.05 & 6.09 & \\
\hline & 6 & 6.05 & 6.02 & 5.99 & 6.00 & 5.97 & 5.94 & 5.99 & \\
\hline & Mean & 6.12 & 6.10 & 6.09 & 6.07 & 6.05 & 6.04 & & \\
\hline \multirow{4}{*}{$\begin{array}{l}\text { Total sugars } \\
(\%)\end{array}$} & 0 & 14.12 & 14.12 & 14.12 & 14.46 & 14.46 & 14.46 & 14.29 & \multirow{4}{*}{$\begin{array}{l}T=0.010 \\
S=0.02 \\
S \times T=0.034\end{array}$} \\
\hline & 3 & 14.34 & 14.28 & 14.49 & 14.57 & 14.49 & 14.54 & 14.40 & \\
\hline & 6 & 14.56 & 14.61 & 14.80 & 14.72 & 14.86 & 14.92 & 14.77 & \\
\hline & Mean & 14.34 & 14.34 & 14.47 & 14.56 & 14.61 & 14.64 & & \\
\hline \multirow{4}{*}{$\begin{array}{l}\text { Reducing sug- } \\
\text { ars (\%) }\end{array}$} & 0 & 12.14 & 12.14 & 12.14 & 12.18 & 12.18 & 12.18 & 12.16 & \multirow{4}{*}{$\begin{array}{l}T=0.014 \\
S=0.02 \\
S \times T=0.035\end{array}$} \\
\hline & 3 & 12.16 & 12.30 & 12.41 & 12.29 & 12.21 & 12.26 & 12.27 & \\
\hline & 6 & 12.58 & 12.63 & 12.73 & 12.74 & 12.59 & 12.64 & 12.65 & \\
\hline & Mean & 12.29 & 12.36 & 12.43 & 12.40 & 12.33 & 12.36 & & \\
\hline \multirow{4}{*}{$\begin{array}{l}\text { Ascorbic acid } \\
(\mathrm{mg} / 100 \mathrm{~g})\end{array}$} & 0 & 9.43 & 9.43 & 9.43 & 9.17 & 9.17 & 9.17 & 9.30 & \multirow{4}{*}{$\begin{array}{l}T=0.010 \\
S=0.019 \\
S \times T=0.034\end{array}$} \\
\hline & 3 & 8.31 & 7.80 & 8.13 & 7.93 & 8.04 & 8.12 & 8.05 & \\
\hline & 6 & 7.20 & 6.17 & 6.84 & 6.90 & 6.91 & 7.08 & 6.82 & \\
\hline & Mean & 8.31 & 7.80 & 8.13 & 8.00 & 8.04 & 8.12 & & \\
\hline \multirow{4}{*}{$\begin{array}{l}\beta \text {-carotene } \\
(\mathrm{mg} / 100 \mathrm{~g})\end{array}$} & 0 & 153 & 153 & 153 & 103 & 103 & 103 & 128 & \multirow{4}{*}{$\begin{array}{l}T=0.015 \\
S=0.021 \\
S \times T=N S\end{array}$} \\
\hline & 3 & 133 & 123 & 113 & 83 & 83 & 83 & 103 & \\
\hline & 6 & 123 & 103 & 83 & 70 & 70 & 60 & 85 & \\
\hline & Mean & 137 & 127 & 117 & 86 & 86 & 82 & & \\
\hline \multirow{4}{*}{$\begin{array}{l}\text { Total phenols } \\
(\mathrm{mg} / 100 \mathrm{~g})\end{array}$} & 0 & 3.55 & 3.55 & 3.55 & 3.23 & 3.23 & 3.23 & 3.39 & \multirow{4}{*}{$\begin{array}{l}T=0.014 \\
S=0.02 \\
S \times T=0.035\end{array}$} \\
\hline & 3 & 3.09 & 3.05 & 3.09 & 2.88 & 2.87 & 2.87 & 2.97 & \\
\hline & 6 & 2.63 & 2.56 & 2.64 & 2.54 & 2.51 & 2.52 & 2.57 & \\
\hline & Mean & 3.09 & 3.05 & 3.09 & 2.88 & 2.87 & 2.87 & & \\
\hline
\end{tabular}

where, $\mathrm{T}=$ treatment, $\mathrm{S}=$ storage, $\mathrm{CD}_{0.05}$ is $5 \%$ level of significance

The mean TSS during storage for 6 months increased from 15.73 to $16.27^{\circ} \mathrm{B}$ and 15.78 to $16.28^{\circ}$ Brix in cold and hot extracted; pulp in with maximum value was noticed in treatment $\mathrm{T}_{4}$ - (pasteurization) while mean minimum was observed in $\mathrm{T}_{1}$ (KMS 2000ppm) in both types of extracted pulp. Statistically, significant differences were found in all the treatments. Increase in TSS during storage may be due to breakdown of polysaccharides into oligosaccharides and monosaccharides. Similar increase in TSS was recorded by Hussain et al. (2003) on storing cold extracted mango pulp using preservatives at $30-45^{\circ} \mathrm{C}$ for 150 days,
Elsheikh et al. (2014) in canned mango concentrate prepared using cold extracted pulp stored under room and refrigerated temperature, Bhardwaj and Mukherjee (2011) in kinnow juice developed by pasteurization at $75^{\circ} \mathrm{C}$ for 15 min stored in glass bottles for 6 months and Sharma (2019) in hot extracted persimmon (Hachiya) pulp (10\% addition of water and 5 min of cooking time) stored for 6 months while contradict results were revealed by Sarkar et al. (2015) for tomato pulp obtained by treating at $95 \mathrm{C}$ for $5 \mathrm{~min}$ when stored in glass bottles for 150 days.

Further, treatments, as well as storage period, had a 
significant $(p<0.05)$ effect on titratable acidity of persimmon pulp. Among the treatments, the mean value for titratable acidity ranged from 0.09 to 0.15 per cent in the cold extracted pulp. In case of hot extracted pulp, mean value for titratable acidity and $\mathrm{pH}$ ranged from 0.09 to 0.13 per cent and 6.04 to 6.12 , respectively with mean minimum value of titratable acidity in treatment $T_{4}$ and maximum in $T_{3}$. With respect to increased titratable acidity, there was a significant decrease in $\mathrm{pH}$ of all the treatments during a storage period of 6 months. During storage, it was observed that pulp preserved with heat treatment had increased acidity to a very lesser extent in comparison to simple chemical preservation method. The increasing trend in titratable acidity during storage has also been noticed by Durrani et al. (2010) in apple pulp extracted simply using pulper machine, Jain et al. (2011) in papaya pulp obtained by boiling pieces for 30 min followed by mixing, Kaur and Aggarwal (2014) in bitter gourd juice obtained from juicer extractor and Dhiman et al. (2018) in pumpkin pulp prepared using $5 \%$ water and cooked for $5 \mathrm{~min}$. The changes in total sugars and reducing sugars of persimmon pulp during storage reflected an increasing trend in all treatments. Mean value of total sugars in cold extracted pulp inclined from 13.79 to 14.28 per cent and for reducing sugars from 11.73 to 12.23 per cents. While the mean value of total and reducing sugars in hot extracted pulp rose from 14.29 to 14.77 and from 12.16 to 12.65 per cent for 6 month storage period. The mean maximum value for total sugar was observed in $T_{6}$ while reducing sugars was observed in $T_{3}$. Statistically, significant differences were found among all the treatments and storage intervals their interaction was also noticed as significant. An increase in total sugars of mango pulp, during 6 months of storage was observed by Kalra and Tandon
(1985). Similarly, Dhiman et al. (2018) observed an increase in reducing sugars of pumpkin pulp during 6 months of storage. Hydrolysis of polysaccharides helped in increasing the quantity of total and reducing sugars.

On the other hand, different bioactive components such as ascorbic acid, $\beta$-carotene and total phenols get decreased with increase in storage period. Both treatments, as well as storage periods, reflected a significant difference among these components. In case of ascorbic acid about 14 to 16 and 20 to 22 per cent decrease in content and 15 to 31 and 30 to 33 per cent decrease in $\beta$-carotene was observed in the cold and hot extracted pulp, respectively in treatment $T_{4}, T_{5}$ and $T_{6}$ during storage (Fig. 1). The decrease in ascorbic acid content from 14.993 to 12.510 and 9.303 to $6.820 \mathrm{mg} / 100 \mathrm{~g}, \beta$-carotene from 213 to 153 and 128 to $85 \mu \mathrm{g} / 100 \mathrm{~g}$ and total phenol from 3.613 to 2.781 and 3.39 to $2.57 \mathrm{mg} / 100 \mathrm{~g}$ was observed in cold and hot extracted pulp, respectively during storage. The effect of treatment, storage interval was noticed to be significant $(p<0.05)$ while their interaction was nonsignificant $(p<0.05)$ in case of $\beta$-carotene. Although the initial value for these components in hot extracted pulp was lesser than the amount present in the cold extracted pulp heating protects the pulp from microbes and retains these components during storage.

There was a significant decrease in the ascorbic acid content of all the treatments during a storage period. The interaction between storage intervals and treatments was found to be significant. The loss in ascorbic acid might be due to the oxidation of irreversible conversion of L-ascorbic acid into dehydroascorbic acid oxidase caused by trapped or residual oxygen in the glass bottles (Jaiswal et al., 2008). The present results are in accordance to Sarkar et al. (2015) for tomato

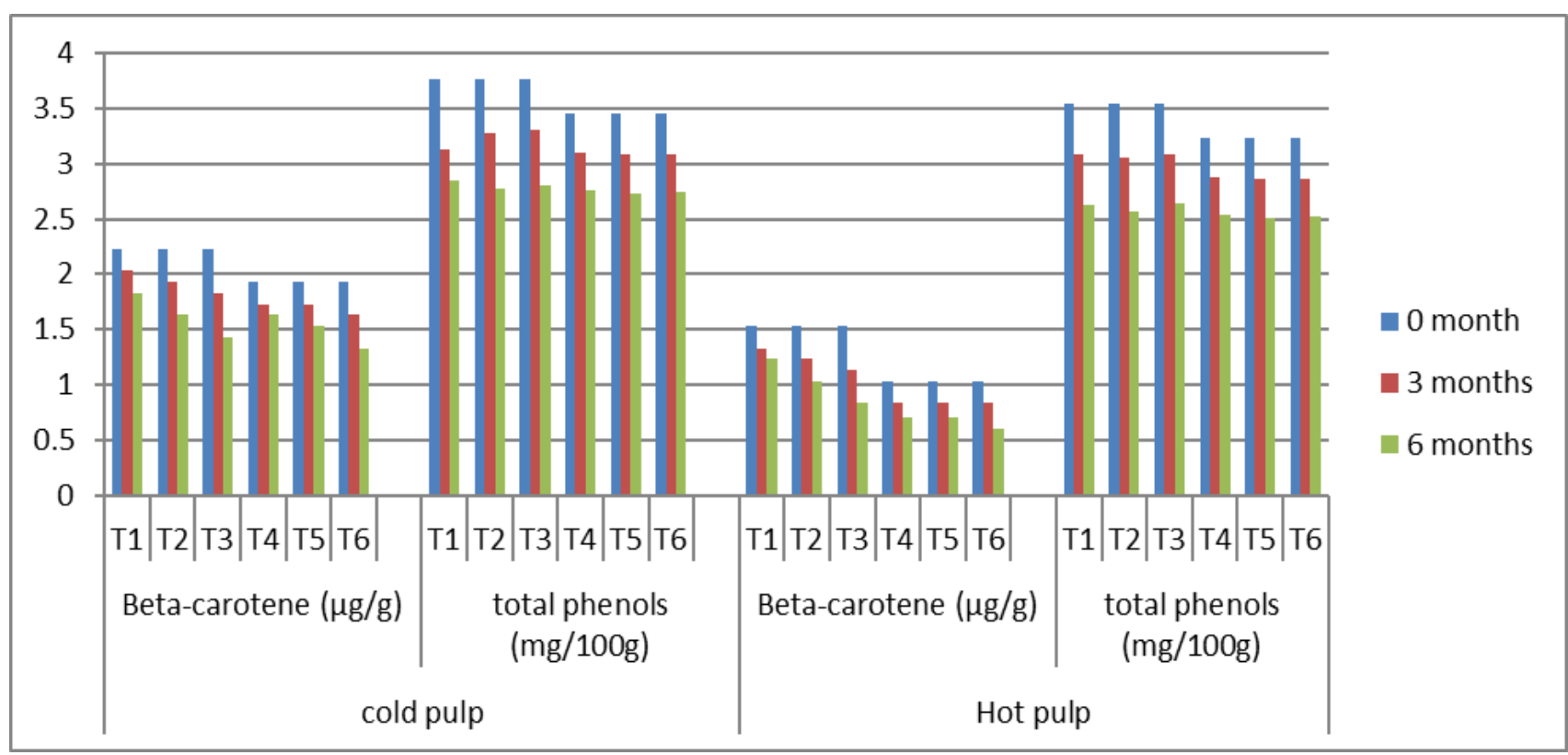

Fig. 1. Effect of storage on quality of $\beta$-carotene and total phenols in cold and hot extracted pulp. 
pulp obtained by treating it at $95^{\circ} \mathrm{C}$ for 5 min when stored in glass bottles for 150 days by Dhiman et al. (2018) in pumpkin pulp prepared, using $5 \%$ water cooked for $5 \mathrm{~min}$. A loss in carotenoid content of product during storage credibly owes to the oxidative breakdown, isomerisation or enzyme destruction of the pigments (Dhiman et al., 2018). A similar effect on $\beta$ carotene was observed by Singh et al. (2017) on storing mango pulp in a different type of packaging material. The reduction in total phenols during storage can be due to the formation of polymeric compounds complex by the interaction of phenols with protein and their precipitates (Kumar and Manimegalai, 2005). Therefore, it was observed that during storage the functional components such as ascorbic acid, $\beta$-carotene and total phenols was retained to a greater extent in case of persimmon pulp preserved by pasteurization followed by chemical treatment in comparison to simple chemical treatments. The samples for the microbial count in persimmon pulp after processing and preservation possessed no growth at 0 months in all the treatments. However, a few microbial (5-20 CFU) growths were observed during storage interval, but the count was below the safe limit (50 CFU) as précised by FSSAI (2006).

\section{Conclusion}

Henceforth, the present study demonstrated the effect of varying water concentrations on the nutritional quality of persimmon (Diospyros kaki L.) pulp prepared by the cold and hot pulping method. The treatment $\mathrm{T}_{2}$ (10 $\%$ water) in cold pulping method and $\mathrm{T}_{5}(10 \%$ water +10 minutes cooking time) in hot pulping method was found to be the best with required quantity of nutrients and higher sensory attributes. Further, it was also seen during the storage that different preservation methods had a significant $(p<0.05)$ effect on titratable acidity, total sugars, reducing sugars, ascorbic acid and total phenols of the pulp. Although many researchers have used a simple method for the extraction of pulp using pulper or juice extractor. The present investigation examined the quality of persimmon pulp in respect of using the peel, addition of water and cooking time, therefore was found to be suitable to obtain the pulp high nutritional characteristics. This work can be a major contribution that can help to develop a nutritionally rich persimmon pulp that has safer and viable storage to be used at the household level as well as industrial level.

\section{ACKNOWLEDGEMENTS}

The authors sincerely thank Dr Anju K Dhiman, Head, Department of Food Science and Technology, College of Horticulture, Dr YS Parmar University of Horticulture and Forestry, Nauni, Solan, Himachal Pradesh, India for providing the facilities to complete this review work.

\section{Conflict of interests}

The authors declare that they have no conflict of interests.

\section{REFERENCES}

1. Amerine, M. A., Pangborn, R. M. and Roessler, E. B. (1965). Principles of sensory evaluation of food. Academic Press, London, pp 236-268.

2. Bembem, K. and Sadana, B. (2013). Effect of cooking methods on the nutritional composition and antioxidant activity of potato tubers. International Journal of Food and Nutritional Sciences, 4: 26-30.

3. Bhardwaj, R. L. and Mukherjee, S. (2011). Effects of fruit juice blending ratios on kinnow juice preservation at ambient storage condition. African Journal of Food Science, 5: 281-286.

4. Bubba, M. D., Giordani, E., Pippucci, L., Cincinelli, A., Checchini, L. and Galvan, P. (2009). Changes in tannins, ascorbic acid and sugar contents in astringent persimmon during on-tree growth and ripening and in response to different post harvest treatments. Journal of Food Composition and Analysis, 22: 668-677. https://doi.org/10.1016/ j.jfca.2009.02.015

5. Butt, M. S., Sultan, M. T., Aziz, M., Naz, A., Ahmed, W., Kumar, N. and Imran, N. (2015). Persimmon (Diospyros kaki) fruit: hidden phytochemicals and health claims. Experimental and Clinical Sciences Journal, 14: 542-561. https://doi:10.17179/excli2015-159

6. Dhiman, A. K., Babu, N. G., Attri, S. and Ramachandran, P. (2018). Preparation of pumpkin pulp and effect of different preservation methods on chemical and sensory properties during storage. Journal of Pharmacognosy and Phytochemistry, 4 : 943-49.

7. Durrani, Y., Ayub, M., Muhammad, A. and Ali, A. (2010). Physico chemical response of apple pulp to chemical preservatives and antioxidant during storage. Internet Journal of Food Safety, $20: 20-28$.

8. Elsheikh, A. O. K., Elazeem, A., Nour, A. M. and Elkhalifa. (2014). Effect of storage on the quality attributes of concentrates of two mango (Mangifera indica) varieties grown in Sudan. British Journal of Applied Science and Technology, 4(14) : 2069-2078.

9. FAO. (2018). Persimmon production in 2017; crop/world regions/production quantity. Food and Agriculture Organization of the United Nations: Division of Statistics (FAOSTAT). Retrived September 202019.

10.FSSAI. (2006). Food safety standards (food products standards and food additive) regulations 2011. Retrived August 262019 from www.fssai.gov.in/portals/0/FSSAI regulations.pdf.

11. Hussain, S., Rehman, S., Randhawa, M. A. and Iqbal, M. (2003). Studies on physicochemical, microbiological and sensory evaluation of mango pulp storage with chemical preservatives. Journal of Research Science, $14:$ 01-09.

12.Itoo. (1980). Persimmon is tropical and sub-tropical fruit; composition, properties and uses. (Nagy $S$ and Show PE eds.). AVI, Westport: CT, pp 442-68.

13.Jain, P. K., Jain, P. and Nema, P. K. (2011). Quality of guava and papaya fruit pulps as influenced by blending ratio and storage period. American Journal of Food Technology, 6 : 507-512. https://doi:10.3923/ajtt.2011.507.512

14.Jaiswal, R., Singh, G. and Singh, A. K. (2008). Evaluation of aonla (Emblica officinalis G.) cultivars for squash mak- 
ing. Progressive Agriculture, 8 : 29-31.

15.Jung, S. T., Park, Y. S., Zachwieja, Z., Folta, M., Barton, H. and Piotrowicz, J. (2005). Some essential phytochemicals and the antioxidant potential in fresh and dried persimmon. International Journal of Food Science and Nutrition, 56 : 105-13. https://doi:10.1080/09637480500081571

16.Kalra, S. K. and Tandon, D. K. (1985). Physico-chemical change in mango pulp during ambient storage in glass containers. Journal of Food Science and Technology, 22 : 350-353.

17.Kaur, G. and Aggarwal, P. (2014). Storage studies on bottle gourd preserved with different chemical additives. Indian Journal of Applied Research, 4 : 39-41. https:// doi:10.15373/2249 555X/FEB2014/65

18.Khattak, J. Z. K., Hussain, A., Ahmad, B., Rehman, M. F., Ullah, Z., Arshad, Z. and Hussain, A. (2014). Microbiological stability of chemically preserved apricot pulp. International Journal of Advancements in Life Sciences, 1 : 15359.

19.Kumar, S. and Manimegalai, G. (2005). Studies on storage stability of whey based papaya juice blended RTS beverage. Journal of Food Science and Technology, 42 : 185-188.

20.Pott, I., Marx, M., Neidhart, S., Mühlbauer, W. and Carle, R. (2003). Quantitative determination of $\square$-carotene stereoisomers in fresh, dried, and solar-dried mangoes (Mangifera indica L.). Journal of Agriculture and Food Chemistry, 51 : 4527-4531. http:// doi:10.1021/jf034084h.

21.Ranganna S. (2009). Handbook of Analysis and Quality Control for Fruit and Vegetable Products. Tata McGraw Hill, New Delhi, 1112p.

22.Sandhu, K. S., Singh, M. and Ahluwalia, P. (2001). Studies on processing of guava into pulp and leather. Journal of Food Science and Technology, 38 : 622-24.

23.Sarkar, S., Roy, D. K. D., Alomoni., Siddik, M. A. B., Das, K. and Rahman, M. J. (2015). Effect of chemical preservatives and storage conditions on the nutritional quality of tomato pulp. American Journal of Food and Nutrition, 3 (4) : 90-100. http://pubs.sciepub.com/ajfn/3/4/1

24.Sharma, A. (2019). Studies on preparation and preservation of persimmon (Diospyros kaki L.) pulp and its utilization in dairy products. M. Sc. Thesis. Dr YS Parmar University of Horticulture and Forestry, Nauni, Solan (HP).

25.Siloni, S. (2013). Development and evaluation of hypoglycaemic guava products with aloevera fortification. M. Sc. Thesis. Dr YS Parmar University of Horticulture and Forestry, Nauni, Solan (HP).

26.Singelton, V. L. and Rossi, J. A. (1965). Colorimetry of total phenolics with phosphomolybedic phosphotungstic acid reagent. American Journal of Enology and Viticulture, $16: 144-58$

27.Singh, K., Rakha, R., Kumar, R. and Singh, M. (2017). Studies on quality parameters in mango pulp stored in containers at different temperatures. International Research Journal of Advanced Engineering and Science, 2 (1) : 208-210.

28.Unal, H., Akbudak, B., Yener, T. and Tokatli, N. (2018) Changes in some physical characteristics of persimmons (Diospyros kaki L.) subjected to different treatments and storage periods. International Journal of Chemical Studies, $6: 955-62$.

29.Zhou, C., Zhao, D., Sheng, Y., Tao, J. and Yang, Y. (2011). Carotenoids in fruits of different persimmon cultivars. Molecules, 16 : 624-36. https://doi:10.3390/molecule s16010624 